\title{
Assessing Industrial Nuclear Reactor Risk using Incident Reporting Risk Matrix Method
}

\author{
Mehrzad Zandieh ${ }^{\mathrm{a},{ }^{*}}$ \\ a Department of Chemical Engineering, Faculty of Engineering, \\ Razi University, Kermanshah, Iran \\ Corresponding author:*Mehrzad.zandieh@yahoo.com
}

\begin{abstract}
This novel study assessed industrial nuclear reactor risk using incident reporting risk matrix. It has also investigated the dangers, causes leading to dangers and their effects and it has identified the occurrence possibilities and intensity of consequences. Moreover, risk levels have been obtained. It was found that $17 \%, 61 \%$, and $22 \%$ of the risks were unlikely, weak, and possible, respectively. The same are $\mathbf{2 6 \%}, \mathbf{3 9 \%}$ and $35 \%$ of the hazards with moderate, major and severe consequences, respectively. Also, according to the risk matrix, $4 \%, 26 \%$ and $70 \%$ of the risks have low, medium and high levels of risk, respectively. Those risks having the risk level of high, were in need of control and preventive actions. Due to this reason, control and preventive actions suitable with consequences and risk effects were proposed and presented. These control and preventive actions were generally placed in the design phase including thermal design, hydraulic design as well as process control.
\end{abstract}

Keywords: Risk assessment, Nuclear reactor, Incident reporting risk matrix

\section{Introduction}

Human societies' need toward reliable energy resources for sustainable development and increasing global sensitivity regarding the reduction of environmental pollutions specially radioactive materials have lead the research be accelerated in the field of nuclear studies [1]. Nuclear reactor refers to equipment in which nuclear chain fission reaction is done continuously and through being under control. In a nuclear reactor, neutrons are used for heavy nuclear fissions. Heavy nuclear fission leads to the production of lighter nuclear, thermal energy and various neutrons. Nuclear reactor not only includes purified nuclear fuel networks, but also includes fuel cooling system during chain reaction simultaneous with energy production such that constituent materials of heart not be damaged structurally [2]. The heart of a nuclear reactor includes some integrated fuels, each of which is consisted of some holder fuel bars and liquid cooling networks [3]. The most important application of nuclear fission reactors is in huge nuclear power plants. The output of nuclear reactor is water vapor with a high pressure and temperature. This vapor produces electricity through rolling turbine and finally generator. Security aspects are of utmost importance, since we should care about the dangers of radioactive materials [2]. Risk is an inevitable factor in projects that if ignored or not managed properly, it would be impossible to control the circumstance [4]. Risk assessing is a versatile method for managing effective equipment in security processing units to reduce the risk resulting from various events. Nowadays, using risk assessing methods have a growing speed and various methods are used for identifying the dangers and risk assessing [5]. Risk assessing is a logical method for investigating the dangers focusing on identifying the dangers and their potential consequences on the individuals, materials, equipment and environment. In fact, by doing so, valuable data for decision making is obtained which mainly includes reducing danger risks (through control and preventive actions), planning for emergency conditions, acceptable risk levels, inspection and keeping policies in industrial installations [6]. In this research, assessing industrial nuclear reactor risk has been investigated for the first time using incident reporting risk matrix method. 


\section{Methodology}

To assess the risks, incident reporting risk matrix method has been utilized.

Remembrance 1: Risk assessing should be conducted by two perspectives of the possibility of risk occurrence in the future according to the guidance Table 1 as well as its consequences on the purposes as stated in the guidance Table 2 .

Guidance Table 1: The possibility of risk occurrence in the future

\begin{tabular}{|c|c|}
\hline Possibility percentage & Occurrence possibility \\
\hline Less than $1 \%$ & Rare \\
\hline $1 \%-20 \%$ & Unlikely \\
\hline $21 \%-50 \%$ & Possible \\
\hline $51 \%-90 \%$ & Likely \\
\hline More than $90 \%$ & Almost certain \\
\hline
\end{tabular}

Guidance Table 2: Risk occurrence consequence in the future

\begin{tabular}{|c|c|}
\hline Explaining the consequence of risk occurrence & The intensity of the consequence \\
\hline It has an insignificant effect on the purpose of nuclear reactor*. & Insignificant \\
\hline It has a minor effect on the purpose of nuclear reactor. & Minor \\
\hline It has a moderate effect on the purpose of nuclear reactor. & Moderate \\
\hline It has a major effect on the purpose of nuclear reactor. & Major \\
\hline It has a severe effect on the purpose of nuclear reactor. & Severe \\
\hline *In industrial measurements, the purpose of nuclear reactor is producing energy (electricity energy). \\
\hline
\end{tabular}

Guidance Table 3: Risk prioritizing

\begin{tabular}{|c|c|c|c|c|c|c|}
\cline { 2 - 7 } \multicolumn{4}{c|}{} & \multicolumn{7}{c|}{ Consequence Intensity } \\
\hline \multirow{3}{*4}{} & Status & insignificant & minor & moderate & major & Severe \\
\cline { 2 - 8 } & $\begin{array}{c}\text { Almost } \\
\text { certain }\end{array}$ & Medium & High & High & Severe & Severe \\
\cline { 2 - 8 } & Likely & Medium & Medium & High & Severe & Severe \\
\cline { 2 - 8 } & Possible & Low & Medium & Medium & High & Severe \\
\cline { 2 - 7 } & Unlikely & Low & Low & Medium & High & High \\
\cline { 2 - 7 } & Rare & Low & Low & Low & Medium & High \\
\hline
\end{tabular}

Table 4: Guidance table for the risks

\begin{tabular}{|c|c|c|}
\hline Actions & Guidance for accepting the risk & Risk status \\
\hline $\begin{array}{c}\text { Immediate actions should be taken to eliminate the } \\
\text { risk source. }\end{array}$ & Not acceptable & Severe \\
\hline $\begin{array}{c}\text { If possible, actions should be taken in near future to } \\
\text { control the risk. }\end{array}$ & Generally not acceptable & High \\
\hline $\begin{array}{c}\text { If possible, action should be taken in far future to } \\
\text { control the risk. }\end{array}$ & Generally acceptable & Medium \\
\hline $\begin{array}{c}\text { Informing related individuals about the existing risk } \\
\text { and applying more observance }\end{array}$ & Acceptable & Low \\
\hline
\end{tabular}




\section{Results and discussions}

The table of identifying and assessing as well as controlling risks have been specified and presented below.

Table 5: Risk assessing table using incident reporting risk matrix method

\begin{tabular}{|c|c|c|c|c|c|c|c|}
\hline \multicolumn{8}{|c|}{ Identifying, assessing and controlling the risk } \\
\hline \multirow[b]{2}{*}{ Row } & \multicolumn{3}{|c|}{ Risk } & \multirow[b]{2}{*}{$\begin{array}{l}\text { The level of } \\
\text { occurrence } \\
\text { possibility }\end{array}$} & \multirow{2}{*}{$\begin{array}{c}\text { The } \\
\text { intensity } \\
\text { of the } \\
\text { consequ } \\
\text { ence }\end{array}$} & \multirow[b]{2}{*}{$\begin{array}{l}\text { Risk } \\
\text { status }\end{array}$} & \multirow{2}{*}{$\begin{array}{l}\text { Suggestive } \\
\text { actions) } \\
\text { control and } \\
\text { preventive } \\
\text { actions) }\end{array}$} \\
\hline & Reasons & Event & $\begin{array}{c}\text { The } \\
\text { consequence on } \\
\text { the purpose of } \\
\text { nuclear reactor }\end{array}$ & & & & \\
\hline 1 & $\begin{array}{l}\text { Creating } \\
\text { deficiency } \\
\text { or disorder } \\
\text { in the } \\
\text { cooling } \\
\text { system }\end{array}$ & $\begin{array}{l}\text { Incorrect energy } \\
\text { balance among } \\
\text { energy production } \\
\text { and cooling rate }\end{array}$ & $\begin{array}{l}\text { Constituting } \\
\text { materials of the } \\
\text { heart of the } \\
\text { reactor are } \\
\text { damaged in } \\
\text { terms of } \\
\text { structure and } \\
\text { geometry. }\end{array}$ & Unlikely & Major & High & $\begin{array}{l}\text { Designing } \\
\text { and using } \\
\text { cooling } \\
\text { intelligent } \\
\text { control } \\
\text { system }\end{array}$ \\
\hline 2 & $\begin{array}{l}\text { Sudden } \\
\text { turn off of } \\
\text { the nuclear } \\
\text { reactor }\end{array}$ & $\begin{array}{l}\text { Increase of } \\
\text { reactor`s heart } \\
\text { temperature due } \\
\text { to the continuance } \\
\text { of decomposition } \\
\text { heat of fission } \\
\text { radioactive } \\
\text { products }\end{array}$ & $\begin{array}{l}\text { Melting and } \\
\text { deteriorating } \\
\text { fuel elements }\end{array}$ & Unlikely & Major & High & $\begin{array}{l}\text { Design and } \\
\text { application } \\
\text { of materials } \\
\text { in fuel } \\
\text { elements } \\
\text { that are } \\
\text { highly } \\
\text { resistant to } \\
\text { severe } \\
\text { temperature } \\
\text { shocks }\end{array}$ \\
\hline 3 & $\begin{array}{l}\text { Inappropria } \\
\text { te design of } \\
\text { the reactor }\end{array}$ & $\begin{array}{l}\text { Unbalance of } \\
\text { losing neutron } \\
\text { rate due to } \\
\text { absorbing and } \\
\text { leakage with the } \\
\text { production rate of } \\
\text { neutron }\end{array}$ & $\begin{array}{l}\text { Not having } \\
\text { sustainable } \\
\text { chain reaction } \\
\text { and as a result, } \\
\text { not having a } \\
\text { constant energy } \\
\text { production rate }\end{array}$ & Unlikely & Major & High & $\begin{array}{l}\text { Engineered } \\
\text { and exact } \\
\text { designing of } \\
\text { the reactor }\end{array}$ \\
\hline 4 & $\begin{array}{l}\text { Melting } \\
\text { and } \\
\text { collapse of } \\
\text { nuclear } \\
\text { reactor`s } \\
\text { heart }\end{array}$ & $\begin{array}{l}\text { Induction of high } \\
\text { positive reactivity }\end{array}$ & $\begin{array}{l}\text { Releasing high } \\
\text { energy (small } \\
\text { nuclear } \\
\text { explosion) }\end{array}$ & Rare & Severe & High & $\begin{array}{l}\text { Exact and } \\
\text { engineered } \\
\text { thermal } \\
\text { designing of } \\
\text { the reactor }\end{array}$ \\
\hline 5 & $\begin{array}{l}\text { Complete } \\
\text { exit of } \\
\text { control bar } \\
\text { with the } \\
\text { highest } \\
\text { radioactive } \\
\text { value } \\
\end{array}$ & $\begin{array}{c}\text { Significant } \\
\text { deviation in the } \\
\text { spatial } \\
\text { independent of } \\
\text { time figure }\end{array}$ & $\begin{array}{c}\text { Invalidity of } \\
\text { synthetic-point } \\
\text { model }\end{array}$ & Rare & Medium & Low & - \\
\hline 6 & $\begin{array}{l}\text { Retarding } \\
\text { neutrons of } \\
\text { fission }\end{array}$ & $\begin{array}{l}\text { Low error in the } \\
\text { intensity } \\
\text { absorption } \\
\text { regarding nuclear } \\
\text { such as } \mathrm{U}^{238} \text { and } \\
\mathrm{Th}^{232}\end{array}$ & $\begin{array}{l}\text { High error in } \\
\text { estimating fuel } \\
\text { consumption } \\
\text { and changing } \\
\text { the fruitful } \\
\text { materials of } \\
\mathrm{U}^{238} \text { and } \mathrm{Th}^{232} \\
\text { to fission } \mathrm{Pu}^{239} \\
\text { and } \mathrm{U}^{233}\end{array}$ & Possible & Major & High & $\begin{array}{l}\text { Exact and } \\
\text { correct } \\
\text { designing of } \\
\text { the kind and } \\
\text { measure of } \\
\text { neutron } \\
\text { retarding in } \\
\text { the reactor }\end{array}$ \\
\hline
\end{tabular}




\begin{tabular}{|c|c|c|c|c|c|c|c|}
\hline 7 & $\begin{array}{l}\text { Error of } \\
\text { thermal } \\
\text { designing } \\
\text { in the heart } \\
\text { of reactor }\end{array}$ & $\begin{array}{l}\text { Increasing heart } \\
\text { temperature of the } \\
\text { reactor, more than } \\
\text { melting } \\
\text { temperature of } \\
\text { heart components }\end{array}$ & $\begin{array}{l}\text { Melting } \\
\text { reactors` heart } \\
\text { components } \\
\text { (specially fuel } \\
\text { and sheath) }\end{array}$ & Unlikely & Major & High & $\begin{array}{l}\text { Exact and } \\
\text { engineered } \\
\text { thermal } \\
\text { designing in } \\
\text { the heart of } \\
\text { the reactor }\end{array}$ \\
\hline 8 & $\begin{array}{c}\text { Having } \\
\text { fault in } \\
\text { designing } \\
\text { consecutive } \\
\text { processes } \\
\text { of thermal } \\
\text { energy } \\
\text { transferring } \\
\text { resulting } \\
\text { from } \\
\text { nuclear } \\
\text { fission } \\
\end{array}$ & $\begin{array}{l}\text { Rapid temperature } \\
\text { increase in the } \\
\text { sheath }\end{array}$ & $\begin{array}{c}\text { Boiling of } \\
\text { cooling liquid }\end{array}$ & Unlikely & $\begin{array}{c}\text { Moderat } \\
\mathrm{e}\end{array}$ & $\begin{array}{c}\text { Mediu } \\
\mathrm{m}\end{array}$ & - \\
\hline 9 & $\begin{array}{l}\text { Error in } \\
\text { hydraulic } \\
\text { design in } \\
\text { the heart of } \\
\text { the reactor }\end{array}$ & $\begin{array}{l}\text { Increase of loss of } \\
\text { cooling pressure } \\
\text { while crossing } \\
\text { over the heart of } \\
\text { the reactor }\end{array}$ & $\begin{array}{l}\text { Increase of } \\
\text { hydraulic } \\
\text { pressure on the } \\
\text { heart of the } \\
\text { reactor } \\
\text { components and } \\
\text { as a result, } \\
\text { increasing } \\
\text { pumping costs }\end{array}$ & Unlikely & $\begin{array}{c}\text { Moderat } \\
\mathrm{e}\end{array}$ & $\begin{array}{l}\text { Mediu } \\
\mathrm{m}\end{array}$ & - \\
\hline 10 & $\begin{array}{l}\text { Fuel's long } \\
\text { resistance } \\
\text { in the heart } \\
\text { of the } \\
\text { reactor }\end{array}$ & $\begin{array}{l}\text { Failure of fuel } \\
\text { elements }\end{array}$ & $\begin{array}{l}\text { Increase of the } \\
\text { possibility of } \\
\text { radiation } \\
\text { dangers }\end{array}$ & Unlikely & Severe & High & $\begin{array}{l}\text { Exact } \\
\text { designing of } \\
\text { the fuel } \\
\text { retention } \\
\text { time in the } \\
\text { heart of the } \\
\text { reactor } \\
\end{array}$ \\
\hline 11 & $\begin{array}{l}\text { Weak } \\
\text { conduction } \\
\text { of nuclear } \\
\text { fuel (Oxide } \\
\text { or Uranium } \\
\text { Carbide) }\end{array}$ & $\begin{array}{l}\text { High temperature } \\
\text { changes in } \\
\text { nuclear fuel } \\
\text { elements }\end{array}$ & $\begin{array}{l}\text { High thermal } \\
\text { tensions to fuel } \\
\text { elements }\end{array}$ & Rare & Major & $\begin{array}{l}\text { Mediu } \\
\mathrm{m}\end{array}$ & - \\
\hline 12 & $\begin{array}{l}\text {-Breakage } \\
\text { of fuel } \\
\text { sheath } \\
\text {-Breakage } \\
\text { in the } \\
\text { cooling } \\
\text { system of } \\
\text { heart (pipe) } \\
\text { - } \\
\text { Damaging } \\
\text { the case of } \\
\text { heart of the } \\
\text { reactor }\end{array}$ & $\begin{array}{l}\text { Release of } \\
\text { radioactive } \\
\text { materials }\end{array}$ & $\begin{array}{l}\text { Highly negative } \\
\text { physical and } \\
\text { environmental } \\
\text { effects }\end{array}$ & Unlikely & Severe & High & $\begin{array}{c}\text { Rapid } \\
\text { control } \\
\text { systems for } \\
\text { tuning off } \\
\text { the reactor } \\
\text { in accident } \\
\text { conditions }\end{array}$ \\
\hline 13 & $\begin{array}{l}\text { Differential } \\
\text { expansion }\end{array}$ & Bucking fuel bar & $\begin{array}{l}\text { Having } \\
\text { instability in } \\
\text { some of the } \\
\text { designs of the } \\
\text { heart of the }\end{array}$ & Unlikely & $\begin{array}{c}\text { Moderat } \\
\mathrm{e}\end{array}$ & $\begin{array}{l}\text { Mediu } \\
\text { m }\end{array}$ & - \\
\hline
\end{tabular}




\begin{tabular}{|c|c|c|c|c|c|c|c|}
\hline & & & reactor & & & & \\
\hline 14 & Fuel ray & $\begin{array}{l}\text { Creating inflation } \\
\text { in the fuel }\end{array}$ & $\begin{array}{l}\text { Creating } \\
\text { pressure on the } \\
\text { sheath }\end{array}$ & Possible & $\begin{array}{c}\text { Moderat } \\
\mathrm{e}\end{array}$ & $\begin{array}{l}\text { Mediu } \\
\mathrm{m}\end{array}$ & - \\
\hline 15 & $\begin{array}{l}\text { Gas } \\
\text { productions } \\
\text { of fission }\end{array}$ & $\begin{array}{l}\text { Having pressure } \\
\text { on the sheath }\end{array}$ & $\begin{array}{l}\text { Form change of } \\
\text { fuel bar in high } \\
\text { temperature } \\
\text { (Jumping to } \\
\text { high } \\
\text { temperature) }\end{array}$ & Possible & $\begin{array}{c}\text { Moderat } \\
\text { e }\end{array}$ & $\begin{array}{l}\text { Mediu } \\
\mathrm{m}\end{array}$ & - \\
\hline 16 & $\begin{array}{l}\text { Temperatur } \\
\text { e changes }\end{array}$ & $\begin{array}{l}\text { Huge thermal } \\
\text { slopes in the } \\
\text { symmetry line of } \\
\text { fuel needle to the } \\
\text { sheath }\end{array}$ & $\begin{array}{l}\text { Breakage of the } \\
\text { sheath in the } \\
\text { radiation } \\
\text { environment of } \\
\text { the heart of the } \\
\text { reactor }\end{array}$ & Possible & Major & High & $\begin{array}{c}\text { Designing } \\
\text { and } \\
\text { constructing } \\
\text { sheath from } \\
\text { materials } \\
\text { having high } \\
\text { resistance } \\
\text { against } \\
\text { thermal } \\
\text { changes }\end{array}$ \\
\hline 17 & $\begin{array}{l}\text { Reactor`s } \\
\text { turning on } \\
\text { and off }\end{array}$ & $\begin{array}{c}\text { Temperature } \\
\text { changes occurring } \\
\text { while turning on } \\
\text { and off the reactor }\end{array}$ & $\begin{array}{l}\text { Breakage of the } \\
\text { sheath in the } \\
\text { radiation } \\
\text { environment of } \\
\text { the heart of the } \\
\text { reactor }\end{array}$ & Possible & Major & High & $\begin{array}{l}\text { Designing } \\
\text { and } \\
\text { constructing } \\
\text { sheath from } \\
\text { materials } \\
\text { having high } \\
\text { resistance } \\
\text { against } \\
\text { thermal } \\
\text { changes }\end{array}$ \\
\hline 18 & $\begin{array}{l}\text { If the AC } \\
\text { electricity } \\
\text { of the } \\
\text { cooling } \\
\text { system of } \\
\text { the reactor } \\
\text { and } \\
\text { supporting } \\
\text { diesel } \\
\text { generators } \\
\text { not work } \\
\text { and } \\
\text { reactors be } \\
\text { put against } \\
\text { severe } \\
\text { dangers of } \\
\text { extreme } \\
\text { heat } \\
\text { without } \\
\text { having } \\
\text { cooling } \\
\text { system }\end{array}$ & $\begin{array}{l}\text { A hot nuclear of a } \\
\text { reactor, without } \\
\text { having a } \\
\text { permanent } \\
\text { resource of } \\
\text { cooling materials, } \\
\text { continuously } \\
\text { vapors the water } \\
\text { around fuel bars } \\
\text { to the extent that } \\
\text { fuel bars are } \\
\text { placed above } \\
\text { water level. In } \\
\text { case fuel bars are } \\
\text { places above the } \\
\text { cooling materials, } \\
\text { they may be } \\
\text { melted and the hot } \\
\text { radioactive fuel } \\
\text { may remain in the } \\
\text { store having } \\
\text { reactor. }\end{array}$ & $\begin{array}{l}\text { In the worst } \\
\text { state of melting, } \\
\text { the mixture of } \\
\text { melted fuel is } \\
\text { melted by metal } \\
\text { case, disposing } \\
\text { alternative } \\
\text { amounts of } \\
\text { radioactive } \\
\text { radiations } \\
\text { against out } \\
\text { world through } \\
\text { crossing over } \\
\text { later obstacle } \\
\text { that are } \\
\text { designed for } \\
\text { keeping nuclear } \\
\text { materials. }\end{array}$ & Unlikely & Severe & High & $\begin{array}{l}\text { Pumping } \\
\text { the water } \\
\text { having } \\
\text { various } \\
\text { mineral } \\
\text { component } \\
\text { to the inside } \\
\text { of the } \\
\text { nuclear of } \\
\text { the reactor } \\
\text { along with } \\
\text { the injection } \\
\text { of Boric } \\
\text { acid as the } \\
\text { absorbent of } \\
\text { neutron to } \\
\text { the inside of } \\
\text { the reactor }\end{array}$ \\
\hline 19 & $\begin{array}{l}\text { Zirconium } \\
\text { reaction of } \\
\text { fuel bars } \\
\text { with the } \\
\text { cooling } \\
\text { water in a } \\
\text { high }\end{array}$ & $\begin{array}{l}\text { Gathering of } \\
\text { produced } \\
\text { hydrogen } \\
\text { resulting from the } \\
\text { reaction }\end{array}$ & $\begin{array}{l}\text { Destruction of } \\
\text { outer walls of } \\
\text { the reactor due } \\
\text { to the } \\
\text { exploitation }\end{array}$ & Unlikely & Severe & High & $\begin{array}{l}\text { Designing } \\
\text { intelligent } \\
\text { thermal } \\
\text { control } \\
\text { system for } \\
\text { the reactor }\end{array}$ \\
\hline
\end{tabular}




\begin{tabular}{|c|c|c|c|c|c|c|c|}
\hline & temperature & & & & & & \\
\hline 20 & $\begin{array}{l}\text { Reducing } \\
\text { the cooling } \\
\text { water level }\end{array}$ & $\begin{array}{l}\text { Placement of fuel } \\
\text { bars outside of the } \\
\text { water level }\end{array}$ & $\begin{array}{l}\text { Severe damage } \\
\text { to fuel bars }\end{array}$ & Unlikely & Major & High & $\begin{array}{c}\text { Using } \\
\text { intelligent } \\
\text { controllers } \\
\text { for } \\
\text { controlling } \\
\text { the cooling } \\
\text { water level }\end{array}$ \\
\hline 21 & $\begin{array}{l}\text { Impairment } \\
\text { of the } \\
\text { cooling } \\
\text { system } \\
\text { along with } \\
\text { operator`s } \\
\text { faults }\end{array}$ & $\begin{array}{l}\text { Melting of } \\
\text { Reactor core }\end{array}$ & $\begin{array}{l}\text { Exiting some of } \\
\text { the dangerous } \\
\text { radioactive } \\
\text { radiations from } \\
\text { the reactor }\end{array}$ & Unlikely & Severe & High & $\begin{array}{c}\text { Using } \\
\text { assisting } \\
\text { cooling } \\
\text { system that } \\
\text { the time a } \\
\text { fault } \\
\text { happens in } \\
\text { the main } \\
\text { cooling } \\
\text { system, it } \\
\text { intelligently } \\
\text { and } \\
\text { automaticall } \\
\text { y, it } \\
\text { circulates } \\
\text { the cooling } \\
\text { fluid, and } \\
\text { prevents } \\
\text { nuclear } \\
\text { reactor`s } \\
\text { melting. }\end{array}$ \\
\hline 22 & $\begin{array}{l}\text { Impairment } \\
\text { of the } \\
\text { cooling } \\
\text { pumps of } \\
\text { the reactor }\end{array}$ & $\begin{array}{c}\text { Reactor's } \\
\text { nuclear } \\
\text { melting } \\
\text { - High } \\
\text { temperat } \\
\text { ure of the } \\
\text { center of } \\
\text { the } \\
\text { reactor } \\
\text { - Destructi } \\
\text { on of } \\
\text { fuel bars } \\
\text { of the } \\
\text { reactor }\end{array}$ & $\begin{array}{l}\text { Distributing } \\
\text { radioactive } \\
\text { materials }\end{array}$ & Unlikely & Severe & High & $\begin{array}{c}\text { Using } \\
\text { assisting } \\
\text { and } \\
\text { supporting } \\
\text { pumps that } \\
\text { are } \\
\text { automaticall } \\
\text { y entered to } \\
\text { the orbit the } \\
\text { time main } \\
\text { pumps are } \\
\text { not } \\
\text { working, so } \\
\text { they } \\
\text { circulate the } \\
\text { cooling } \\
\text { liquid. }\end{array}$ \\
\hline 23 & $\begin{array}{l}\text { Meltdown } \\
\text { of the } \\
\text { central part } \\
\text { of the } \\
\text { reactor }\end{array}$ & $\begin{array}{l}\text { Melting atomic } \\
\text { fuel cylinders and } \\
\text { other parts of the } \\
\text { reactor }\end{array}$ & $\begin{array}{l}\text { High leakage of } \\
\text { radioactive } \\
\text { materials to the } \\
\text { surrounding } \\
\text { environment } \\
\text { and high } \\
\text { pollution }\end{array}$ & Rare & Severe & High & $\begin{array}{c}\text { Exact } \\
\text { thermal } \\
\text { designing of } \\
\text { the reactor }\end{array}$ \\
\hline
\end{tabular}


Table 6: Possibility percentage share of various risks

\begin{tabular}{|c|c|c|}
\hline Row & Possibility occurrence level (\%) & Kind \\
\hline 1 & 17 & Rare \\
\hline 2 & 61 & Unlikely \\
\hline 3 & 22 & Possible \\
\hline
\end{tabular}

Table 7: Intensity of consequences` percentage share regarding various risks

\begin{tabular}{|c|c|c|}
\hline Row & Intensity of the consequence & kind \\
\hline 1 & 26 & Moderate \\
\hline 2 & 39 & Major \\
\hline 3 & 35 & Severe \\
\hline
\end{tabular}

Table 8: Levels` percentage share of various risks

\begin{tabular}{|c|c|c|}
\hline Row & Risk level (\%) & Kind \\
\hline 1 & 4 & Low \\
\hline 2 & 26 & Medium \\
\hline 3 & 70 & High \\
\hline
\end{tabular}
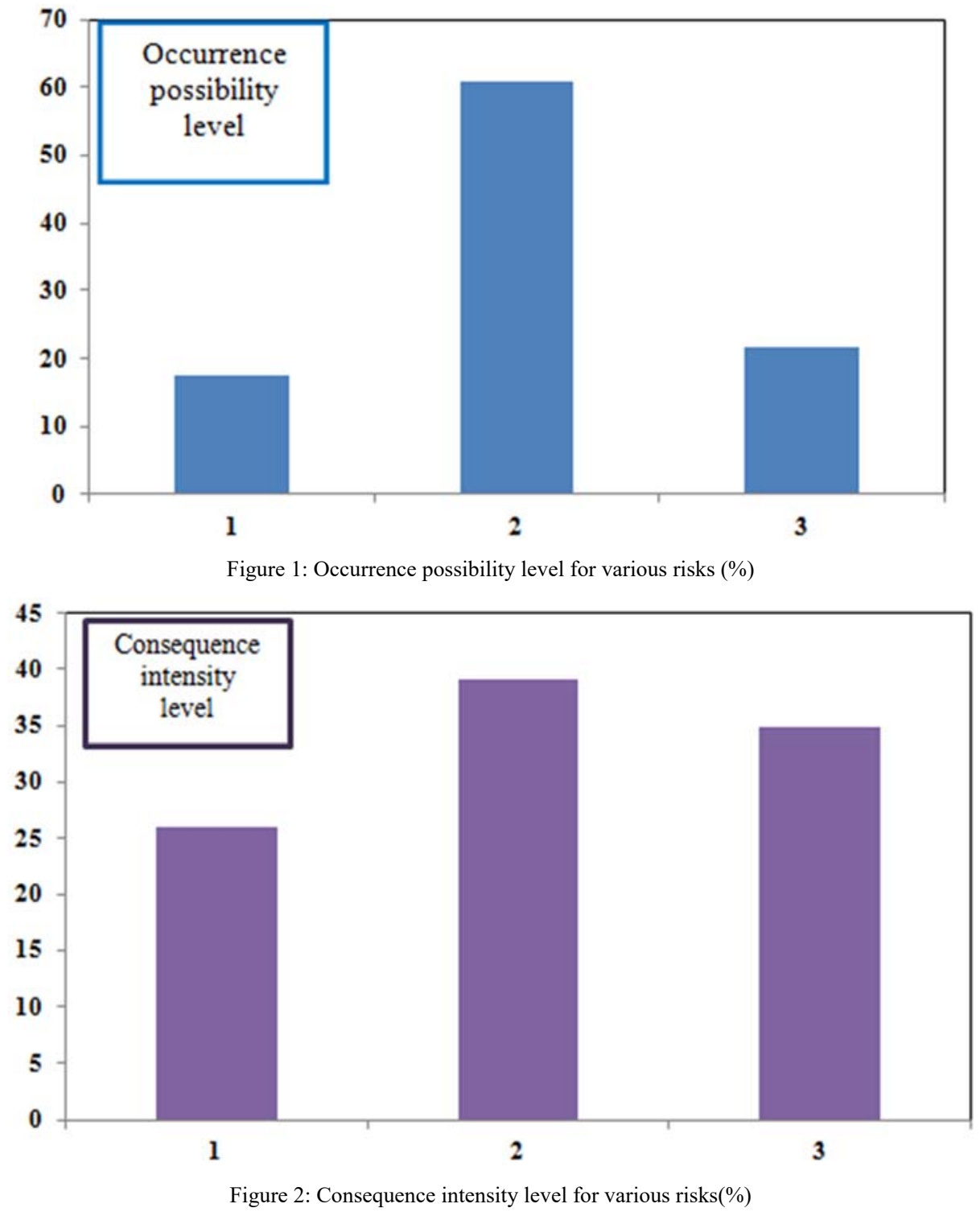


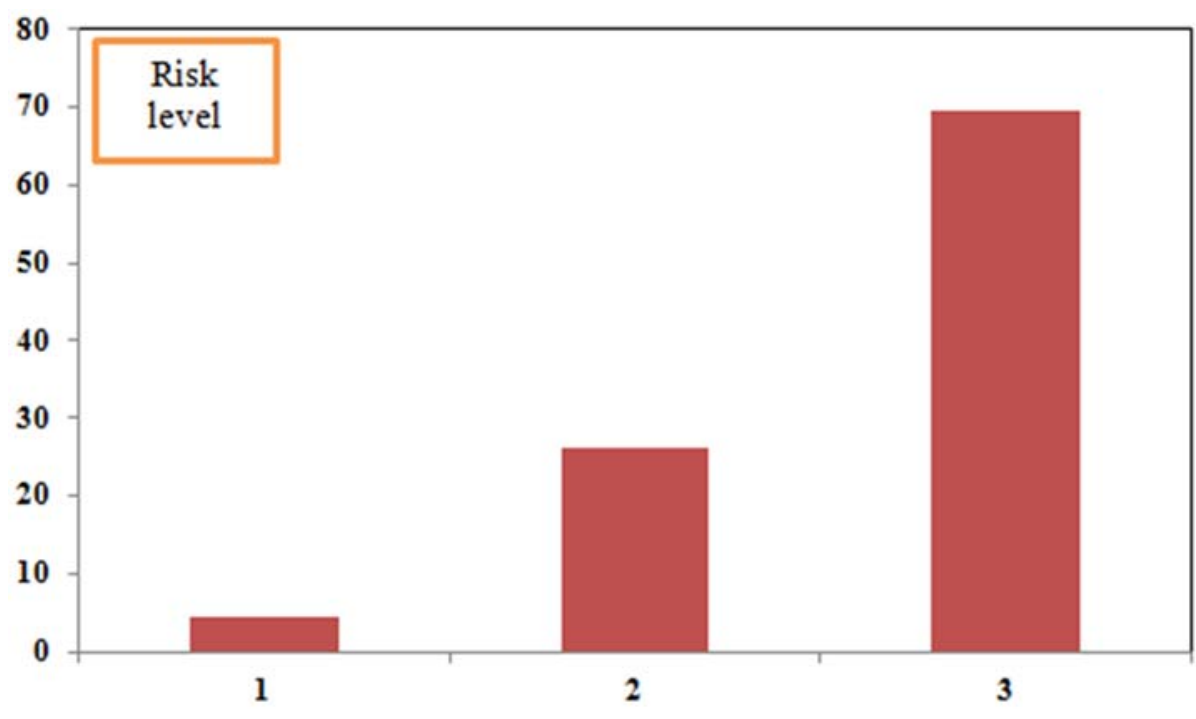

Figure 3: Risk level for various risks (\%)

According to Table 5, based on incident reporting risk matrix method, 23 important dangers with dangerous factors and consequences as well as related effects were identified.

It was revealed that $17 \%, 61 \%$ and $22 \%$ of dangers had the occurrence possibility of rare, unlikely and possible, respectively (Table 6 , Figure 1); this means that most of the risks had the occurrence possibility of unlikely and possible ( $83 \%)$. Accordingly, $26 \%, 39 \%$ and $35 \%$ of dangers had the consequence intensity of moderate, major and severe (Table 7, Figure 2); this means that most of the risks had the consequence intensity of major and severe $(74 \%)$, which is due to the nature of the reactor (nuclear reactor) and its related consequences. Considering risk matrixes, $4 \%, 26 \%$ and $70 \%$ of the dangers had a risk levels equivalent to low, medium and high (Table 8, Figure 3). 8 risks had the occurrence possibility, consequence intensity and risk level equal to unlikely/rare (6 of them were unlikely and 2 of them were rare), severe and high. These were more severe than others. These types of risks were related to the risks and consequences of these effects, including radioactive radiation and the emission of hazardous radiation to the environment and the highly hazardous (human and environmental) damage caused by them and the same explosion in the reactor due to damage to the internal wall caused by the explosion of the nuclear reactor. 16 group of risks needed control and preventive actions. Risks having risk levels of high, needed control and preventive actions. Therefore, control and preventive actions suitable with consequences and risk effects were suggested and presented (Table 5). These control and preventive actions generally included designing and using appropriate material in fuel elements, using appropriate neutron controllers, accurate thermal designing according to heat transfer principles, exact designing of the fuel retention time and appropriate design of the fuel sheath (in terms of material, structure and geometrical form). Moreover, control actions discussion includes reactor control systems in accident conditions, controlling reactor temperature, controlling cooling water's level as well as appropriate and intelligent designing in the cooling system of the reactor.

\section{Discussion}

This study was conducted with the aim of analyzing industrial nuclear reactor's risk. It was revealed that control and preventive actions are of utmost importance in the designing phase. The first and dangerous responsibility of nuclear reactor's design of the heart is taken by nuclear engineer. Various aspects of designing such as thermal-hydraulic design, structural and geometrical design are important. It includes designing indexes, applicable discussions, reliability, security and etc. As it was indicated in the risk assessing table, in case errors take place in nuclear reactor's design and process, various dangers and consequences resulting from that as well as irreparable effects would happen in nuclear reactor process. Risk assessing is a powerful and capable instrument for avoiding and preventing such dangers and their consequences.

\section{References}

[1] T Hamacher and A M Bradshaw, "Fusion as a Future Power source: Recent achievements and Prospects", 18 th World Energy Congress Energy Markets: The Challenges of the New Millennium, Buenos Aires, Argentina 21, 2001.

[2] Mohammad Reza Iskandari, Rashid Shah Hosseini, Fatemeh Alikaii, Nuclear Reactor Analysis, Nuclear Science and Technology Research Institute Publications, 2011.

[3] M.M. EL-Wakil, Nuclear Heat Transport, $3^{\text {rd }}$ Edition, The American Nuclear Society, USA ,(1981).

[4] Habibi, E.A. Applied safety and performance Indicators in the industry. Second edition, Fanavaran Publishing House, 358 pages, 2007.

[5] Hyatt N. Guidelines for process hazards analysis, hazards identification \& Risk analysis. CRS press;.P1-12, 2003.

[6] Nivo Lianito, Z., . Risk Analysis and Risk Management: A European in sight Law, Probability and Risk, 1(2): 161- 174, 2002 